Pratiques et expériences de l'enquête - I

\title{
A French Maoist Experience in Brazil. Robert Linhart's Investigation of Sugarcane Workers in Pernambuco
}

\section{Marcelo Hoffman}

\section{(2) OpenEdition \\ 12 Journals}

\section{Electronic version}

URL: https://journals.openedition.org/grm/2162

DOI: $10.4000 / \mathrm{grm} .2162$

ISSN: $1775-3902$

Publisher

Groupe de Recherches Matérialistes

Electronic reference

Marcelo Hoffman, "A French Maoist Experience in Brazil. Robert Linhart's Investigation of Sugarcane Workers in Pernambuco", Cahiers du GRM [Online], 16 | 2020, Online since 07 July 2020, connection on 07 December 2022. URL: http://journals.openedition.org/grm/2162 ; DOI: https://doi.org/10.4000/ grm.2162

This text was automatically generated on 28 December 2020 .

All rights reserved 


\title{
A French Maoist Experience in Brazil. Robert Linhart's Investigation of Sugarcane Workers in Pernambuco
}

\author{
Marcelo Hoffman
}

\section{Introduction}

1 Robert Linhart is a towering figure in the history of French Maoism. As one of Louis Althusser's most distinguished students at the École Normale Supérieure, Linhart founded the Union of Marxist-Leninist Communist Youth (UJCML) in 1966. The UJCML was a Maoist organization that set out to establish contact with the masses to build an authentically revolutionary party. It attempted to fulfill this goal in the summer of 1967 through the practice of the enquête (investigation) among workers and peasants. The UJCML then sought to intensify and deepen its contact with the masses through a shift in emphasis to établissement as the far more immersive practice of putting militants to work in factories to organize workers ${ }^{1}$. The UJCML broke up in the summer of 1968 under the weight of contending interpretations of the events of May 1968 as well as outright state proscription but the practices of the investigation and établissement would persist among other Maoist groups in France ${ }^{2}$. Linhart himself served as an établi (a militant who took up the practice of établissement) at the Citröen automobile factory in Porte de Choisy between September 1968 and July 1969. He gained prominence for his profoundly moving memoir of his eye-opening and challenging experiences there. Published appropriately enough as L'établi in 1978 and translated as The Assembly Line in 1981, Linhart's memoir belongs to a sequence of his books published from 1976 to $1980^{3}$. Linhart's first book, Lénine, les paysans, Taylor (Lenin, the peasants, Taylor), was published in $1976^{4}$. It is a critical exploration of the agrarian policies and Taylorist organization of industrial labor instituted by Lenin and the Bolsheviks after the October 1917 revolution in Russia. His last book, Le sucre et la faim. Enquête dans les 
régions sucrières du nord-est brésilien (Sugar and hunger. Investigation in the sugar-producing regions of the Brazilian Northeast) was published in $1980^{5}$. It is a short memoir of his investigation of sugarcane workers in the state of Pernambuco in Brazil in 1979. In his preface to the 2010 edition of Lénine, les paysans, Taylor, Linhart synthesized the themes in all of his books. "In a way ", he wrote, « one could say that these different books complement one another and constitute an ensemble : it deals with the Taylor system, the peasant movement, resistance to exploitation $»^{6}$.

2 I want to explore Linhart's least-known contribution to this ensemble in the Englishspeaking world, namely Le sucre et la faim ${ }^{7}$. The exploration of the details of this memoir is not simply a matter of addressing a grossly overlooked and underappreciated contribution. It also has rich implications for interpretations of the overlapping histories of French Maoism and the militant investigation. The first thing to note about Linhart's book is its lengthy subtitle. It bears the name of a practice that punctuated the experience of French Maoism through and through. That word is, of course, investigation. The mere presence of that word in the full title of a book written by the former leader of a Maoist group responsible for the inauguration of the practice of the investigation among French Maoists is noteworthy. It suggests the possibility of a lingering fidelity to the Maoist investigation. But a consideration of Linhart's book as the narration of the enactment of a Maoist investigation runs straight into an elementary problem. Linhart did not frame his investigation in Brazil as a Maoist undertaking. He barely even mentioned his Maoism. Linhart opted instead for the far more anodyne self-identification of a «French journalist $»^{8}$. Yet, if we scratch the surface of his narrative and situate it within a much wider context of the history of Maoism in France and China as well as the overall history of the militant investigation, Linhart's investigation in Brazil appears to us as unmistakably Maoist in its method, social focus, style, and animating desire.

3 Why would a short narrative about a relatively obscure investigation conducted a little over four decades ago in rural Pernambuco deserve our attention today? Why would it matter that Linhart undertook a Maoist investigation there? Uncertainties and anxieties about the economic rise of China over the last few decades have facilitated a resurgence of interest in the global journey of Maoism. Julia Lovell's newly published and widely acclaimed book Maoism : A Global History recounts that journey in elaborate detail ${ }^{9}$. She suggests that Maoism traversed the globe by tapping into local grievances and aspirations, especially after the Sino-Soviet split. Yet, in spite of her appeal to a promising conceptualization of Maoism as an ensemble of contradictory phenomena, Lovell tends to dilute the complexity of Maoism by focusing overwhelmingly on its violent practices and legacies. Linhart's narrative of his French Maoist investigation in Brazil offers us a very different perspective on the global journey of Maoism. His narrative concerns the enactment of a practice that sought to produce a knowledge of political possibilities rather than the realization of political objectives through the imposition of violence. Linhart's narrative thus acts as a counterweight to Lovell's analysis. What we get from it is a greater measure of nuance in analyses of the global journey of Maoism. Linhart's displacement of the Maoist investigation from France to Brazil also casts the intersecting histories and geographies of French Maoism and the militant investigation in a new light. By the time Linhart undertook his Maoist investigation in Brazil in 1979, the ascendance of more liberal forces opposed to Marxism had been well underway in France ${ }^{10}$. The broad turn to liberalism and away 
from revolution undermined the radicalism that had facilitated the deployment of the militant investigation inside and outside French Maoism. Yet these developments did not stop Linhart from resuscitating a Maoist investigation in another national context. He reactivated that form of the investigation in Brazil long after Maoism and the militant investigation had peaked in popularity in France in the early 1970s. Linhart thus contributes to a reframing of the spatial and temporal parameters of French Maoism and the militant investigation. Finally, his narrative enables us to expand the ways in which we think about what stamps an investigation with a militant character. Linhart attunes us to the importance of imagination and memory in disclosing and nurturing the desire for revolution in the very process of a militant investigation.

\section{A Maoist Investigation in Rural Pernambuco}

4 Linhart undertook his investigation in rural Pernambuco during a two-week period in late September 1979. The immediate occasion for his visit to Brazil was the return of the former governor of Pernambuco, Miguel Arraes, to the country after more than a decade in exile. Linhart accompanied Arraes on the journey from Paris to Recife ${ }^{11}$. Shortly after his arrival in Recife, Linhart went straight to a city with the pseudonym of the Highland Princess ${ }^{12}$. Based on the geographical details of his narrative, that city seems to have been Timbaúba in the interior of Pernambuco ${ }^{13}$. Linhart then returned to Recife $^{14}$. From there he went to the southern portion of the zona da mata and a westerly portion of Pernambuco before heading to a city with the one-letter pseudonym « $\mathrm{N}$ » and the Galiléia sugar mill ${ }^{15}$.

5 Linhart's activities during his journey through the interior of Pernambuco certainly lived up to the all-important reference to the investigation in the subtitle of his book. Those activities consisted mainly in posing questions to others in their spaces of habitation and work in order to elicit their responses. Linhart then used the responses to build his narrative. When pressed about the purpose of his presence in and around the sugar plantations of Pernambuco, Linhart presented himself as a French journalist. However, he only identified as such in the face of hostile questions or potential problems ${ }^{16}$. Linhart never pro-actively adopted the identity of a French journalist outside these circumstances in his narrative. His book also does not indicate any newspapers or magazines where its content had been previously published. It therefore seems that Linhart's self-identification as a French journalist amounted to a mere cover. There were certainly good reasons to maintain that cover rather than undertake an openly Maoist investigation. The military dictatorship in Brazil had brutally eliminated Maoist guerillas in the Araguaia river basin only a few years beforehand ${ }^{17}$. The label of foreign journalist had the advantage of allowing Linhart to more easily access spaces and maneuver across the social spectrum in Pernambuco without arousing suspicions of subversion that may have even extended to his collaborators and interviewees.

6 It is also important to remember that Linhart was not conducting his investigation alone. He relied on the support of at least two Brazilians, a student named Reynaldo and a union advisor named Antonio ${ }^{18}$. If political circumstances forced Linhart to adopt the semblance of an impartial outsider, Antonio and Reynaldo were not so reserved about their political orientations. In one episode, Reynaldo departed from the question and answer format of the investigation to implore three agricultural workers to 
organize ${ }^{19}$. In another episode, Antonio took Linhart to a favela to distribute pamphlets to encourage the residents to vote in favor of a general strike at an upcoming union meeting. The political impetus behind Linhart's investigation also became clear in the unfolding of his narrative. What initially caught his attention was the apparent absence of any political mobilization on the part of the opposition in the Northeast at a time when other regions of Brazil erupted in $"$ strikes and demonstrations $»^{20}$. Linhart found this situation peculiar because of the extreme poverty of the Northeast and its rich history of peasant mobilizations prior to the establishment of the military dictatorship in 1964. He undertook an investigation to explore the possibilities of the reawakening of the peasant movement at the very moment that a protracted economic crisis undermined the perceived legitimacy of the dictatorship among its most ardent supporters.

7 Linhart's decision to launch an investigation in an ostensibly pacified space was certainly not without precedent in the history of militant investigations. The founding editor of Quaderni Rossi, Raniero Panzieri, had encouraged contributors to the journal to conduct workers' inquiries at a large FIAT factory in Turin in the early 1960s precisely because that factory had not experienced the kinds of intense struggles among workers that had occurred at other automobile factories in Italy. Panzieri wanted to explore whether the FIAT workforce harbored the possibilities for a more antagonistic orientation beneath the surface of social peace ${ }^{21}$. As Andrea Cavazzini clarifies, it was not political struggle but the very lack of it that served as a motivation for Panzieri's call to realize workers' inquiries at the FIAT factory in Turin ${ }^{22}$.

8 Linhart's broadly similar rationale for his investigation in Pernambuco brought it into proximity with the tradition of workers' inquiry. His focus on the conditions and struggles of sugarcane workers also fit neatly within that tradition ${ }^{23}$. Yet here we must draw a distinction that reflects a larger divide within the history of militant investigations. Linhart undertook a Maoist investigation specifically rather than a workers' inquiry (at least in the strict sense) ${ }^{24}$. His activities in Pernambuco bore the hallmarks of a Maoist investigation in various ways.

9 First of all, Linhart did not restrict his questions to members of any particular social class, even though the content of his questions consistently concerned the conditions and struggles of sugarcane workers. His investigation was therefore not a "workers' inquiry » in the strict sense of a practice based on questions directed toward workers alone for the purpose of generating political effects among them. As in the case of Mao's approach to investigations, Linhart sought to grasp the social totality through questions posed to individuals and groups from across the social, political, professional, and generational spectrum. For this purpose, he posed questions to children, day laborers from various racial backgrounds (including one who had been interned at a psychiatric hospital), a peasant who had just lost his baby to diarrhea, a hairdresser, administrators and members of rural workers' unions, an elderly founding member of the Peasant Leagues, a deputy from the state of Acre, a professor with an expertise in nutrition, a foreman, and factory owners. Linhart here implicitly followed Mao in attempting to grasp the social totality through an investigation in order to disclose the possibilities of contesting that totality. The responses to his questions were just as varied as the persons offering them. They concerned the memories of Arraes among sugarcane workers, the costs of membership in rural workers' unions, days off, the length of the working day, the appropriation of plots of land used by the families of 
sugarcane workers for gardening (roçados), urbanization, the use of child labor in the sugar plantations, the impact of inflation on salaries, illiteracy, and the desirability of striking. Perhaps just as important as the verbalized responses to Linhart's questions were his physical encounters with persons who implicitly or explicitly conveyed the experience of hunger ${ }^{25}$. These responses and encounters fed into a composite picture of the relationship between sugar and hunger in Northeast Brazil. Linhart suddenly realized that sugar production produces hunger. In his words :

As I gathered testimonies and information, hunger appeared to me with a terrible clarity as the material and product of a complicated, even sophisticated, apparatus. Hunger was not simply the spectacular, almost accidental absence of available food, as it is presented to us when they want us to believe that charity movements, « emergency relief » would suffice to quench it. The hunger of the Northeast was an essential part of what the military regime called the "development » of Brazil. It was not a simple hunger, a primordial hunger. It was an elaborate hunger, a perfected hunger, a booming hunger, in a word, a modern hunger. I saw it progress in waves, called economic plans, development projects, industrial hubs, investment incentives, mechanization and modernization of agriculture. A lot of work was needed to produce that hunger ${ }^{26}$.

10 In a classically Maoist fashion, Linhart did not stop with this lesson about objective conditions in Northeast Brazil. He also probed the subjective conditions for political mobilization there. Linhart detected signs of a reawakening of the peasant movement in the experience of witnessing a vote in favor of a general strike among sugarcane workers. The vote did not in fact result in the strike because the unions were able to cut a deal with the bosses in advance of the strike date ${ }^{27}$. Still, Linhart interpreted the manifest willingness of the rural workers to strike as a reflection of their determination to adopt a more vigorous oppositional stance ${ }^{28}$. For this reason, he concluded his narrative on the following cautiously hopeful note:

At the height of the terror, a resistance was maintained in the Brazilian peasantry. Now that social pressure and the economic crisis have weakened the dictatorship, we can discern its features. It's like a twilight state, a still pale morning. A landscape emerges from a very dark and very long night. We can see forms we believed were effaced. Everything was therefore there, in movement in the obscurity, ignored. One day, we will know ${ }^{29}$.

11 These deeply evocative words suggest that Linhart's investigation was an exercise in the discernment of previously obscure political forces and possibilities.

Second, the overriding focus of his investigation was on the conditions and struggles of peasants in particular. That focus was perfectly in keeping with Maoism both in its original guise and in its subsequent iterations in France. Of course, Mao's famous investigation of the peasant movement in Hunan in January and February 1927 had led him to highlight the political importance of the peasantry against the more orthodox Marxist emphasis on the industrial proletariat within the Chinese Communist Party $(\mathrm{CCP})^{30}$; He had concluded that the sheer preponderance of poor peasants in China combined with their material destitution rendered them absolutely crucial to the realization of a communist revolution ${ }^{31}$. Mao was also deeply impressed by both the explosion of violent energy that the peasant movement had unleashed against landlords and the abrupt inversion of the social order established in the aftermath of peasant revolts. ${ }^{32}$ For Mao, the peasantry in China amounted to an underappreciated class that could breathe life into the revolution. The situation was no doubt different in the far more industrialized and urbanized context of France in the late 1960s and early 
1970s but even there Maoists of different stripes resuscitated investigations focused on peasants to explore the possibilities of building an alliance between the working class and peasantry ${ }^{33}$. Political circumstances in Pernambuco dictated a more tempered tone about the peasantry. Linhart did not approach it explicitly as a force for a revolution in the near future or as an ally of the working class in the transition to socialism. He treated the peasantry, rather, as an emergent force pregnant with possibilities for resistance to the dictatorship and social hierarchies in Brazil.

Third, there are expressions in Linhart's book that easily recall some expressions in Mao's report of his investigation of the peasant movement in Hunan. Mao had conveyed his bewilderment with what he had learned from others during his investigation there. In the words of the opening paragraph of Mao's report : «I saw and heard of many strange things of which I had hitherto been unaware $»^{34}$. Over fifty years later, Linhart offered a strikingly similar turn of phrase in the opening section of his book. «When I arrived in Recife, » he recalled, «I seized the first opportunity that presented itself to go to the interior of the sugar-producing zone. What I saw there shocked $m e »^{35}$. Linhart's stylistic proximity to Mao on the heels of his experience in the sugar plantations of Pernambuco is unsurprising. Linhart possessed a demonstrable knowledge of the intricacies of Mao's report on the peasant movement in Hunan ${ }^{36}$.

Finally, Linhart reinforces the impression that his investigation in Brazil was of a Maoist derivation by briefly reminding readers of one important episode from his past. In August 1967, Linhart and a handful of other UJCML members went on what appears to have been a highly sugarcoated tour of revolutionary China ${ }^{37}$. Linhart recounts thinking about his visit to a «popular commune » in China during his visit to the Galiléia sugar mill in Brazil at the very end of his investigation ${ }^{38}$. What stirred the memory of his visit to China was the historical and political significance of the sugar mill. In 1959, a movement of evicted peasants known as the Peasant Leagues succeeded in getting the mill appropriated and its lands distributed to peasants. The success of the Peasant Leagues inspired other peasants to organize around the demand for the expropriation of plantations. The Peasant Leagues flourished with the help of Arraes until the dictatorship decimated the movement in the months following the military coup d'état in $1964^{39}$.

What is remarkable about Linhart's visit to Galiléia is that he suddenly uses it as an occasion to imagine what the place would have looked like if Brazil had undergone a revolution. In his words:

If a popular revolution had won in Brazil, Galiléia today would be an important place that delegations from all regions of Brazil and all the countries of the world would visit, where flags would flap and revolutionary songs would reverberate, where images and legends would take shape ${ }^{40}$.

There is a lot going on in this brief but evocative passage. Linhart's description of his own imagination about Galiléia suddenly discloses a desire that lends a force and logic to his entire narrative. One can easily see from it that he desired a Brazil that looked like revolutionary China even as he recognized that it was in fact just the opposite of revolutionary China ${ }^{41}$. It is thus no wonder that at least some of Linhart's expressions recall Mao's expressions. It is also no coincidence that Linart resuscitated a distinctly Maoist investigation focused on the figure of the peasant. He was projecting a desire for a revolutionary China into rural Brazil. Yet we might ask why he rendered Brazil the national space for such a projection. Why not simply continue to imagine a revolutionary China in the French countryside? One basic reason for Linhart's 
displacement of the desire for revolutionary China no doubt concerned the political climate in France. Linhart launched his investigation in Pernambuco at a time when the liberal political and intellectual climate in France discouraged (at the very least) any fidelity to Maoist practices.

In some ways, however, it should not surprise us that Linhart undertook a specifically Maoist investigation in Brazil. He was, after all, a founding figure of the Maoist movement in France and Maoism continued to leave a profound mark on his analyses. In Lénine, les paysans, Taylor, Linhart had used Maoist methods and concepts as well as the overall experience of revolutionary China to evaluate the economic policies of Lenin and the Bolsheviks in the immediate aftermath of the revolution of October $1917^{42}$. Yet, as emphasized in the introduction, Linhart's Maoism remained subdued in Brazil for political reasons. We therefore had to tease out the Maoist underpinnings of his investigation there.

\section{Toward a More Robust Understanding of French Maoism and the Militant Investigation}

What do we get by teasing out these underpinnings? Linhart's narrative of his investigation in Brazil enables us to appreciate the complexity of the global journey of Maoism. To be more precise (and slightly more polemical), his narrative provides a timely counterweight to the analysis in Lovell's new book, Maoism: A Global History ${ }^{43}$. What is significant in her book is the ambition to constitute a history of Maoism as a global phenomenon with massive repercussions for interpretations of the Cold War and developments in our present. Lovell's own gestures to an understanding of Maoism as an ensemble of contradictory phenomena is also extremely fecund for the exploration of Maoist experiences. The core problem is that she does not stick to that understanding. Lovell tends to flatten the global history of Maoism into little more than a one-dimensional and borderline sensational narrative of the transformation of local grievances by Maoists into fanaticism, manipulation, gross hypocrisy, and exponential levels of violence. By contrast, Linhart's narrative of his investigation in Pernambuco reminds us that global Maoism contained a vastly more delicate and experimental streak. The Maoism Linhart practiced in rural Pernambuco was above all about the exploration of political possibilities through a production of knowledge premised on social interactions in the form of the exchange of questions and answers as well as physical encounters.

Linhart's narrative also compels us to refine our understanding of the spatial and temporal parameters of the intersecting experiences of French Maoism and the militant investigation. He projected a practice of investigation into rural Brazil. That practice had grown in popularity in France in the late 1960s and early 1970s after originating with Mao in China in the 1920s. French Maoists themselves had pushed the boundaries of the investigation within France by taking it beyond the figure of the worker in the institutional space of the factory. Inspired by Mao, these Maoists conducted investigations of the peasantry in the French countryside. Linhart in turn engaged in yet another spatial extension of the practice by effecting its displacement to the Brazilian countryside. Yet he did so after the rise of liberal political and intellectual forces in France in the mid-1970s. Those forces precipitated a decline in the radicalism that had nurtured the circulation of the militant investigation inside and outside the 
French Maoist experience. In an illuminating interview with Cavazzini, Yves Duroux reminds us that Linhart tried to breathe life back into the Maoist investigation during this period. In his words :

Some tried to return to it [the investigation] afterwards, especially Linhart. I know because I also participated in it. We tried to find new styles of investigation in the factories. Ultimately more traditional investigations in appearance but with a very elaborate protocol of investigation. This gave rise to two or three things. But in ' 80 everything stopped ${ }^{44}$.

In light of Duroux's observation, one cannot help but wonder whether disappointments with «new styles of investigation » in the factories drew Linhart to practice the investigation in the Brazilian countryside. Whatever the case, Linhart's narrative of his investigation in Brazil suggests that the Maoist investigation did not simply go away after the implosion of French Maoism in the mid-1970s and the peak in popularity of the militant investigation in France at the outset of the 1970s. It survived these moments inside and outside France.

21 Linhart saw no reason to abandon the Maoist investigation, especially in a region of Brazil marked by a rich history of peasant mobilizations. To simply abandon the Maoist investigation would be tantamount to succumbing to anti-Marxist political forces in France in the late 1970s. But there was also a substantive reason to retain and extend the Maoist investigation. The seizure of the social totality at the heart of the method of the Maoist investigation held the promise of disclosing the possibility of a reawakening of the peasant movement.

Finally, the fleeting moments of imagination and memory in Linhart's narrative of his investigation in Brazil contribute to a more robust understanding of the overall practice of the investigation. These moments suggest that a militant investigation need not announce its political objectives in broad daylight in advance of the labor of an investigation. Those objectives can be revealed in moments of imagination and memory in the unfolding process of an investigation. The investigation can be pulled forward by a desire for revolution that inhabits the interstices of imagination and memory about places.

\section{Postscript : Back in Timbaúba}

A geographical detail in Le sucre et la faim may have gone unnoticed in my reading of the book if it had not been for my own personal history as the son of a mother not only from Pernambuco but also from Timbaúba in particular. That detail concerns the identity of the city where Linhart launched his investigation in Brazil. Though he sticks to the pseudonym of the Highland Princess for the city, it appears to have been Timbaúba, as I indicate above. If that was the case, it turns out that Linhart would not have been the last foreigner to launch an investigation in the city. The renowned American anthropologist Nancy Scheper-Hughes engaged in an ethnography of the relationship between " mother love and child death ${ }^{45}$ in the favela of Alto do Cruzeiro in the same city ${ }^{46}$. She conducted her research on four visits there between 1982 and $1989^{47}$. The research became the basis for Scheper-Hughes's massive, illuminating, and deeply moving book, Death Without Weeping: The Violence of Everyday Life in Brazil. Surprisingly, she does not cite Le Sucre et la faim in Death Without Weeping but a brief comparison of the methods behind these books enables us to bring into relief the 
militant underpinnings of Linhart's investigation in Pernambuco from yet another angle. Like Linhart, Scheper-Hughes relied on Brazilian collaborators for her research and interviewed individuals from across the social spectrum in Timbaúba but she spent much more time in the city and already knew it from her previous work in Alto do Cruzeiro as a Peace Corps volunteer in the $1960 \mathrm{~s}^{48}$. Unlike Linhart, Scheper-Hughes was also deeply conflicted about the political character of her undertaking. She initially conducted her research in the more detached guise of an anthropologist who explicitly resisted any political involvement with the members of the community she studied. As Scheper-Hughes recalls explaining to the Brazilian collaborators who asked her to get politically involved, « My work is different now. I cannot be an anthropologist and a companheira [comrade] at the same time $»^{49}$. She adds that she elaborated her « reservations about the propriety of an outsider taking an active role in the life of a Brazilian community $»^{50}$. It was only after Scheper-Hughes's Brazilian collaborators felt outraged at her lack of political involvement (as a deeper sign of a disturbing lack of reciprocity) that she began to play the dual role of an anthropologist and comrade ${ }^{51}$. By contrast, Linhart conducted an implicitly but distinctly Maoist investigation in Pernambuco. If he feigned the more impartial identity of a foreign journalist, he did so only in order to avoid the problems involved in so openly carrying out a militant investigation in the repressive political conditions of Brazil at the time. In other words, there was no conflict between his self-presentation in Pernambuco and the militant aspirations of his investigation. And, more generally, a militant investigation does not flow from a position of detachment.

\section{NOTES}

1. Jason E. Smith, «From Établissement to Lip: On the Turns Taken by French Maoism », in Viewpoint Magazine, September 25, 2013, https://www.viewpointmag.com/2013/09/25/frometablissement-to-lip-on-the-turns-taken-by-french-maoism/; Jean-Pierre Le Dantec, « D'où vient l'établissement? ", in Les Temps Modernes, n 684-85, juillet-octobre 2015, p. 20.

2. Richard Wolin, The Wind from the East: French Intellectuals, the Cultural Revolution, and the Legacy of the 1960s, Princeton, Princeton University Press, 2010, p. 134-37.

3. Robert Linhart, L'établi, Paris, Les Éditions de Minuit, 1978 ; The Assembly Line, trans. Margaret Crosland, Amherst, University of Massachusetts Press, 1981.

4. Robert Linhart, Lénine, les paysans, Taylor, Paris, Seuil, 2010. Unless otherwise noted, all translations are my own.

5. Robert Linhart, Le sucre et la faim: Enquête dans les régions sucrières du nord-est brésilien, Paris, Les Éditions de Minuit, 2003.

6. R. Linhart, Lénine, les paysans, Taylor, op. cit., p. 8.

7. Le sucre et la faim remains untranslated into English, and I am not aware of any sustained engagement with its contents in the English language. Lénine, les paysans, Taylor also remains untranslated into English but it has been the object of at least one illuminating interpretation for English readers. See J.E. Smith, «From Établissement to Lip: On the Turns Taken by French Maoism », op. cit. 
8. R. Linhart, Le sucre et la faim, op. cit., p. 31-32.

9. Julia Lovell, Maoism: A Global History, New York, Alfred A. Knopf, 2019.

10. For an overview of the ascendance of these forces in the context of a study of the influence of Maoism on French intellectuals, see R. Wolin, Wind from the East, op. cit., p. 342-49.

11. R. Linhart, Le sucre et la faim, op. cit., p. 8-9.

12. Ibid., p. 13-40.

13. Ibid., p. 13-14. His description of the geography of the Highland Princess as three hills in the northern part of what is known as the zona da mata (an area of sugar plantations that had once been dense Atlantic forest) matches the city of Timbaúba. Highland Princess (Princesa Serrana) is also a name associated with Timbaúba.

14. Ibid., p. 41-44

15. Ibid., p. 46-93.

16. Ibid., p. 31-32, 65, 73.

17. Elio Gaspari, As ilusões armadas. 2. A ditadura escancarada, 2nd ed., Rio de Janeiro, Intrínseca, 2014, p. 407-73.

18. R. Linhart, Le sucre et la faim, op. cit., p. 13, 65.

19. Ibid., p. 18.

20. Ibid., p. 8.

21. Jamie Woodcock, "The Workers' Inquiry from Trotskyism to Operaismo: A Political Methodology for Investigating the Workplace », ephemera: theory \& politics in organization $14, \mathrm{n}^{\circ} 3$, 2014 , p. 493-513, http://www.ephemerajournal.org/sites/default/files/pdfs/contribution/ 14-3woodcock.pdf.

22. Andrea Cavazzini, Enquête ouvrière et théorie critique: Enjeux et figures de la centralité ouvrière dans l'Italie des années 1960, Liège, Presses Universitaires de Liège, 2013, p. 109.

23. For an effort to interpret Karl Marx's 1880 « A Workers' Inquiry » as a synthesis of his theory and bring elements of it to bear on sugarcane workers in Brazil, see Júlio César Lopardo Alves and José Marçal Jackson Filho, " Trabalho, saúde e formação política na enquete operária de Marx », Trabalho, Educação e Saúde 15, n¹, 2017, p. 13-31, http://dx.doi.org/10.1590/1981-7746-sol00044.

24. For the divide between the Maoist investigation and workers' inquiry within the history of militant investigations, see Marcelo Hoffman, Militant Acts: The Role of Investigations in Radical Political Struggles, Albany, State University of New York Press, 2019, p. 11 et p. 69-70. Amazingly, French Maoists do not appear to have been influenced by or even aware of the roughly contemporaneous tradition of workers' inquiry among Italian workerists, and Italian workerists do not appear to have been explicitly influenced by Mao's practice and theorization of the investigation.

25. R. Linhart, Le sucre et la faim, op. cit., p. 11 et p. 52-53.

26. Ibid., p. 53. The profound impact of Linhart's investigation on his own thinking about hunger is all the more remarkable when one considers that hunger was not a new topic for him. In Lénine, les paysans, Taylor, Linhart had explored of the political implications of the famine in the Soviet Union shortly after the Russian revolution of October 1917. That book even contains a whole chapter titled « Hunger ». Yet the emphasis in Lénine, les paysans, Taylor is not so much on the production of hunger as on the way in which the threat of famine precipitated an authoritarian turn (through the forced collection of wheat and the Taylorist organization of labor in the railway industry) in the early years of the Soviet Union. See R. Linhart, Lénine, les paysans, Taylor, op. cit., especially p. 45-65, 149-50, 161.

27. R. Linhart, Le sucre et la faim, op. cit., p. 84.

28. Ibid., p. 85.

29. Ibid., p. 93.

30. Mao Tsetung, "Report on an Investigation of the Peasant Movement in Hunan " in Selected Readings from the Works of Mao Tsetung, Peking, Foreign Languages Press, 1971, p. 23-39. For a 
detailed discussion of how the emphasis on the peasantry in Mao's report in Hunan challenged Marxist orthodoxy within the CCP, see Rebecca E. Karl, Mao Zedong and China in the TwentiethCentury World, Durham, Duke University Press, 2010, p. 29-32.

31. Mao, « Report on an Investigation of the Peasant Movement in Hunan », op. cit., p. 35.

32. Ibid., p. 25-31.

33. For a rich narrative of the investigations and other activities of one Maoist group in France co-founded by Alain Badiou, see Groupe pour la fondation de l'Union des communistes de France marxiste-léniniste, Le livre des paysans pauvres: 5 années de travail maoïste dans une campagne française, Paris, François Maspero, 1976.

34. Mao, "Report on an Investigation of the Peasant Movement in Hunan », op. cit., p. 23.

35. R. Linhart, Le sucre et la faim, op. cit., p. 9, emphasis mine.

36. R. Linhart, Lénine, les paysans, Taylor, op. cit., p. 41-43 et p. 70. Linhart quotes from Mao's report on the peasant movement in Hunan in two instances in his earlier book on Lenin. He uses excerpts from the report in his elaboration of Lenin's positive attitude toward mass peasant insurrections and in his critique of the hatred of the peasantry among intellectuals after the Russian revolution.

37. R. Wolin, Wind from the East, op. cit., p. 122-25.

38. R. Linhart, Le sucre et la faim, op. cit., p. 91.

39. Nancy Scheper-Hughes, Death Without Weeping: The Violence of Everyday Life in Brazil, Berkeley, University of California Press, 1992, p. 46-49.

40. R. Linhart, Le sucre et la faim, op. cit., p. 91.

41. Ibid.

42. R. Linhart, Lénine, les paysans, Taylor, op. cit., p. 24, 41-43, 70, 75, 77, 91, 96, 102, 133, 175, 196, 199, 209, 213.

43. J. Lovell, Maoism, op. cit..

44. Yves Duroux, "Sur la question du savoir dans le maoïsme ", in Andrea Cavazzini, Le sujet et l'étude : Idéologie et savoir dans le discours maoïste suivi de dialogue avec Yves Duroux, Reims, Le Clou dans le Fer, 2011, p. 106, brackets added.

45. Nancy Scheper-Hughes, Death Without Weeping, op. cit.

46. Ibid.., p. 15.

47. Ibid.

48. Ibid., p. 5.

49. Ibid., p. 17, brackets added.

50. Ibid., p. 17.

51. Ibid., p. 18

\section{ABSTRACTS}

This article teases out the Maoist underpinnings of Robert Linhart's investigation of sugarcane workers in the state of Pernambuco in Brazil in 1979. It contends that his investigation was implicitly but distinctly Maoist in its method, social focus, style, and animating desire. Drawing on the Maoist underpinnings out of Linhart's investigation is important for three reasons: first, it enables us to better appreciate the complexity of what has recently been called the global journey of Maoism; second, it expands the spatial and temporal parameters of the intersecting 
histories of Maoism and the militant investigation; third, it enriches the concept of the Maoist investigation by attuning us to the roles of memory and imagination.

Cet article démêle les fondements maoïstes de l'enquête de Robert Linhart des ouvriers agricoles de canne à sucre dans l'état de Pernambouc au Brésil en 1979. Il affirme que cette enquête était implicitement mais nettement maoïste dans sa méthode, son accent social, son style et son désir animant. S'appuyant sur les fondements maoïstes de l'enquête de Linhart est important pour trois raisons : premièrement, il nous permet de mieux apprécier la complexité de ce qu'on a récemment appelé le voyage mondial de maoïsme; deuxièmement, il élargit les paramètres spatiales et temporales des histoires croisées de maoïsme et de l'enquête militante; troisièmement, il enrichit le concept de l'enquête maoïste par nous faire comprendre les rôles de mémoire et de l'imagination.

\section{INDEX}

Geographical index: France, Brésil, Pernambouc

Keywords: Robert Linhart, Mao Zedong, Nancy Scheper-Hughes, Maoism, investigation, workers' inquiry, peasant, sugarcane workers

Mots-clés: Linhart Robert, Mao Tsé-toung, Nancy Scheper-Hughes, maoïsme, enquête, enquête ouvrière, paysan, ouvrier agricole de canne à sucre

Chronological index: années 1970

\section{AUTHOR}

\section{MARCELO HOFFMAN}

Marcelo Hoffman est chercheur. Il est l'auteur de deux livres, Militant Acts: The Role of Investigations in Radical Political Struggles (State University of New York Press, 2019) et Foucault and Power: The Influence of Political Engagement on Theories of Power (Bloomsbury, 2014). Il est également l'éditeur spécial (sous la direction de Bernard E. Harcourt) du numéro de la revue nord-américaine Carceral Notebooks sur le thème « Foucault and the Politics of Resistance in Brazil ». Ses recherches portent sur le Marxisme, l'histoire de l'enquête militante, Foucault et le Brésil contemporain. Actuellement il est en train d'écrire un manuscrit sur Foucault au Brésil. 